\title{
Large-Scale Synthesis of Few-Layer Graphene from Magnesium and Different Carbon Sources and its Application in Dye-Sensitized Solar Cells
}

Lidong Wang ał, Bing Wei a Jingjie $\mathrm{Wu}^{\mathrm{b}}$, Jun Lou ${ }^{\mathrm{b}}$, Robert Vajtai ${ }^{\mathrm{b}}{ }^{*}$, and Weidong1 Fei a, c, *

\section{Graphical Abstract}

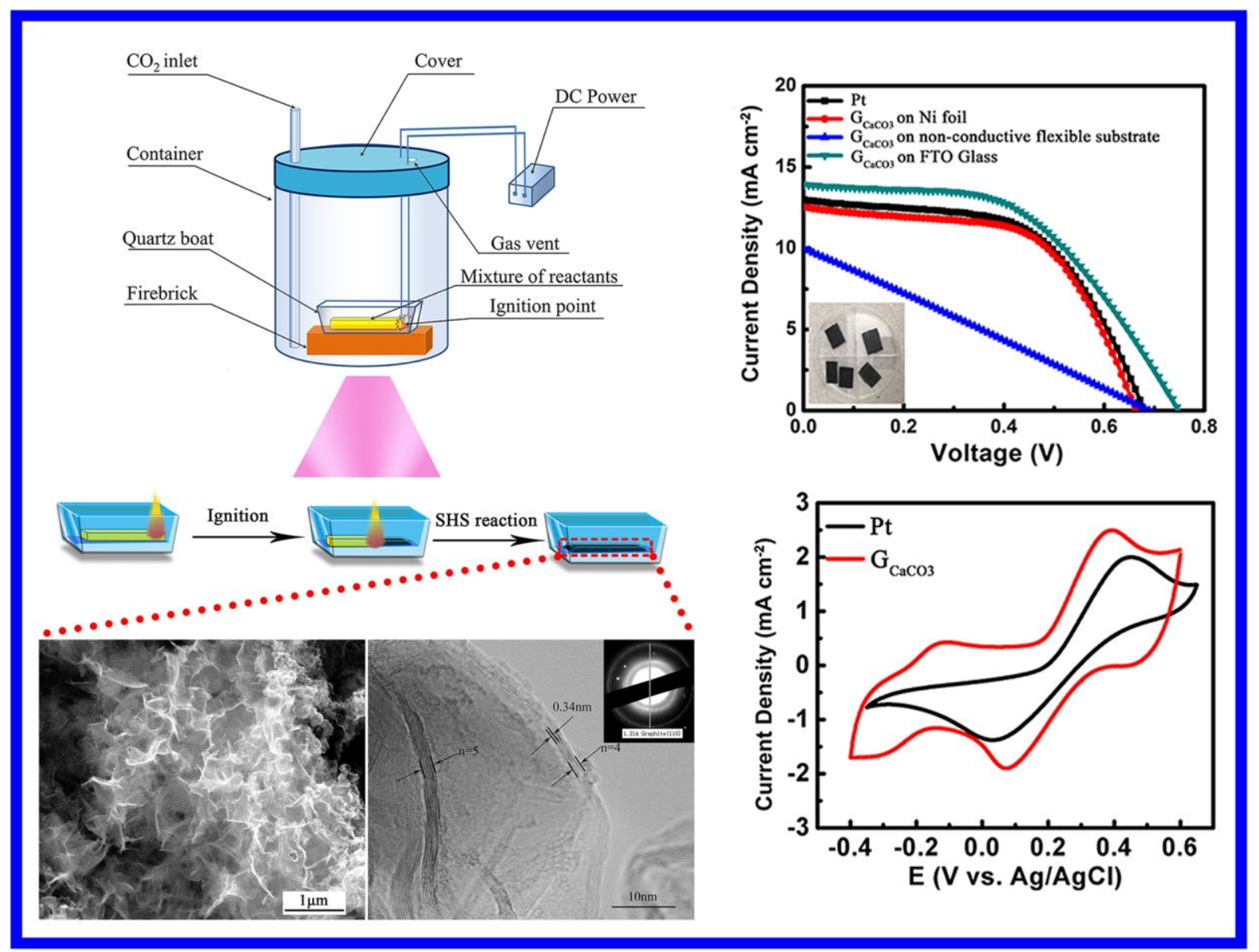

\section{Keywords:}

Self-propagating high-temperature synthesis, Few-layer graphene, Dye-Sensitized Solar Cells.

\section{Abstract}

\footnotetext{
${ }^{a}$ School of Materials Science and Engineering, Harbin Institute of Technology, Harbin, 150001, China. E-mail: wdfei@ hit.edu.cn.

${ }^{b}$ Rice University, Department of Materials Science and NanoEngineering, Houston, TX, USA, 77005. E-mail: Robert.Vajtai@rice.edu.

${ }^{c}$ School of Mechanical Engineering, Qinghai University, Xining 810016, China.

Author Contributions: Author Lidong Wang, Bing Wei, Pei Dong and Qinghua Miao contributed equally to this work.
} 
A self-propagating high-temperature synthesis (SHS) method to synthesize few-layer graphene (FLG) from magnesium and different carbon sources is demonstrated. These carbon sources include $\mathrm{CaCO}_{3}, 3 \mathrm{MgCO}_{3} \cdot \mathrm{Mg}(\mathrm{OH})_{2} \cdot 3 \mathrm{H}_{2} \mathrm{O}$, glucose, and polyvinyl alcohol (PVA). FLG produced by SHS method has a 3D porous structure with a special nanocrystallinity, and a low amount of defects. This fast, energy saving and low cost method is competitive as a candidate for industrial production of graphene for a wide range of applications. It is found that $\mathrm{CaCO}_{3}$ are superior to others among these starting materials according to DSC properties. The dye-sensitized solar cell (DSC) with a FLG (produced from CaCO3) counter electrode (CE) achieves a power conversion efficiency higher than that obtained with a reference DSC using a Pt counter electrode. The charge transfer resistance of FLG DSC is $0.13 \Omega \mathrm{cm}^{2}$, which is more than thirty times lower than that of the DSC having a Pt counter electrode. SHS FLG has been demonstrated to be a promising alternative counter electrode in DSC.

\section{Introduction}

Graphene is a single planar layer of carbon atoms with many amazing properties such as giant intrinsic mobility [1], high thermal conductivity [2], super high strength [3], impermeability to gases [4] and high transparency [5]. All these unique features make graphene a promising and innovative material for many potential applications.

In order to meet the rapidly increasing demand of the graphene from the scientific research and industrial applications, both top-down and bottom-up strategies have been developed to produce graphene. Top-down strategies include such methods as micromechanical cleavage of graphite [6], liquid phase exfoliation of graphite [7, 8], laser exfoliation of highly ordered pyrolytic graphite [9], $\mathrm{H}_{2} \mathrm{O}_{2}$ plasma etching of graphite [10], unzipping of nanotubes [11], and chemical oxidation and reduction method [12-14]; examples of bottom-up methods are chemical vapor deposition (CVD) $[15,16]$, epitaxial growth on SiC [17], arc discharge [18], Shock-wave synthesis [19], conventional calcination from $\mathrm{Mg}$ and 
$\mathrm{CaCO}_{3}$ [20], and reduction of $\mathrm{CO}[21]$ and $\mathrm{CO}_{2}$ (dry ice) [22].

However, most of those techniques suffer from several drawbacks. Firstly, the large amount of the heat or the electricity is needed during the synthesis process for most of these methods except for chemical oxidation and reduction method and $\mathrm{CO}_{2}$ reduction method. Secondly, chemical oxidation and reduction method is efficient and inexpensive, however, strong oxidizing (e.g. $\mathrm{H}_{2} \mathrm{SO}_{4}, \mathrm{HNO}_{3}, \mathrm{KMnO}_{4}$ ) and reductive reagents are hazard and environment unfriendly; and a serious of time consuming steps are also required [13], Thirdly, the dry ice used in $\mathrm{CO}_{2}$ reduction method is easy to sublimate but hard to be stored and hard to control the synthesis process, which makes the method not convenient enough. Consequently, preparing graphene sheets with less energy consumption, simple and low cost process is always a huge challenge.

Self-propagating high-temperature synthesis (SHS) is a method of combustion synthesis, which denotes highly exothermic processes leading to solid-state products [23]. Since its discovery in the early 1970s [24, 25], SHS has attracted more and more attentions as an alternative method to the conventional furnace technology for the synthesis of a variety of advanced materials such as carbides, nitrides, borides and oxides [26-32]. SHS is characterized by the fact that the reaction is initiated at one end of the sample, and selfpropagates through the reactants in the form of a combustion wave at a velocity which varies from 0.1 to $25 \mathrm{~cm} \mathrm{~s}^{-1}$. The combustion wave driving force is the heat energy releasing from the exothermic combustion reactions; accordingly no further energy supply is needed after initialization. With these merits, SHS can provide an efficient way for the industrial production of ceramic powders. However, to the best of our knowledge, SHS has not been applied to synthesis graphene yet.

Here, we demonstrate a simple and facile SHS method to synthesize the few-layer graphene (FLG) by the reaction of magnesium $(\mathrm{Mg})$ with various carbon sources. These carbon sources include inorganic substance $\left(\mathrm{CaCO}_{3}, 3 \mathrm{MgCO}_{3} \cdot \mathrm{Mg}(\mathrm{OH})_{2} \cdot 3 \mathrm{H}_{2} \mathrm{O}\right)$, organic 
small molecule (glucose), and polymer (polyvinyl alcohol) (PVA). Compared with other graphene preparation techniques, SHS method is commercially competitive because it is fast, scalable, and low cost.

The dye-sensitized solar cells (DSC) is the third generation of solar cell, with the promising high conversion efficiency, simple manufacturing, low-cost, and also able to utilize the indoor light resource. It was first reported with the efficiency of 7.1\%-7.9\% in 1991 [33]. General procedures of preparing DSCs have been explored and developed to improve the control group to a reasonable high performance. The current world record is over $14 \%$ [34], achieved by Hanaya's team in 2015. The highest efficiency of DSC with iodine electrolyte is 11.4\% [35]. These solar cells utilize three main components: (1) Dye molecules will absorb the light. (2) The photo anode consists of the semiconducting material, i.e. $\mathrm{TiO}_{2}, \mathrm{ZnO}$ and $\mathrm{WO}_{3}$, with dye molecules attached onside. (3) To regenerate electrons for the dye molecules, the conductive counter electrode will catalyse the electrolyte redox reaction [35].

To achieve the low cost DSC with high efficiency, the proper material for cathode is one of the key factors. The conventional counter electrodes are the fluorine doped tin oxide (FTO) substrates with sputtered Pt thin film onside [36-38]. With the excellent catalytic activity, electrical conductivity, and corrosion resistance, Pt is a good candidate for high-efficiency DSC. Unfortunately Pt is also a relatively rare element and expensive material. To decrease DSC cost and further achieve practical large-scale production, an alternative cathode material with superior electrocatalytic activity as well as excellent high conductivity is highly desirable. Due to the low cost, excellent catalytic activity, high durability, and electrical conductivity, carbon based materials have been utilized as effective alternative counter electrode with low cost for many years [39-42]. Carbon nanohorns and nanotubes [39], carbon black [41] and graphite [42] have all been tested as potential counter electrodes. Graphene-based counter electrodes have been reported [43-48], recently. In the state-of-art Co-mediated DSC, the electrochemical performance of graphene-based DSC can also been improved dramatically 
upon chemical reduction. [46] However, in general, the efficiencies of the DSC with graphene-based counter electrodes in iodine based electrolyte are still lower than that of the DSC with Pt. Therefore, it is still a challenge to develop materials with high performance and low cost as the counter electrode for DSCs. Here, we investigate the effect of SHS graphene synthesized by different carbon sources on the properties of DSC. FLG produced by SHS method has been demonstrated to be a good candidate for counter electrode in DSC.

\section{Experimental}

\subsection{Synthesis of graphene}

Magnesium powder (200 mesh, $99.0 \%$ ), polyvinyl alcohol powder (PVA, Mn=1750), AR grade carbonate salts (Calcium carbonate, $\mathrm{CaCO}_{3}$, basic magnesium carbonate, $\left.3 \mathrm{MgCO}_{3} \cdot \mathrm{Mg}(\mathrm{OH})_{2} \cdot 3 \mathrm{H}_{2} \mathrm{O}\right)$ and AR grade glucose $(99.5 \%)$ were purchased from Sinopharm Chemical Reagent Co., Ltd.. All materials were used as obtained without further purification.

Magnesium powder (16.8 g) was mixed with different carbon sources in a mortar with pestle, respectively; the carbon sources included $35.0 \mathrm{~g}$ of calcium carbonate, $127.8 \mathrm{~g}$ of magnesium carbonate, $21 \mathrm{~g}$ of glucose or $33.6 \mathrm{~g}$ of PVA. The mixture was added into a ceramic boat, which was put into a $21.2 \mathrm{~L}$ stainless-steel combustion chamber $(30 \mathrm{~cm}$ in diameter and $30 \mathrm{~cm}$ in height) under an atmosphere of high purity carbon dioxide (99.9\%) with a flow rate of $0.5 \mathrm{~L} \mathrm{~s}^{-1}$ in the synthesis system. The schematic illustration of the combustion synthesis system is shown in Figure 1. One end of the mixture was ignited by an electric ignition device composed of a DC powder source and a resistant wire heater, the ignition current was $22 \mathrm{~A}$. When the mixture was ignited the reaction was spontaneously propagating through the mixture in a form of a combustion wave from one side to another and the reaction finished when the combustion wave reached the other side of the mixture. 


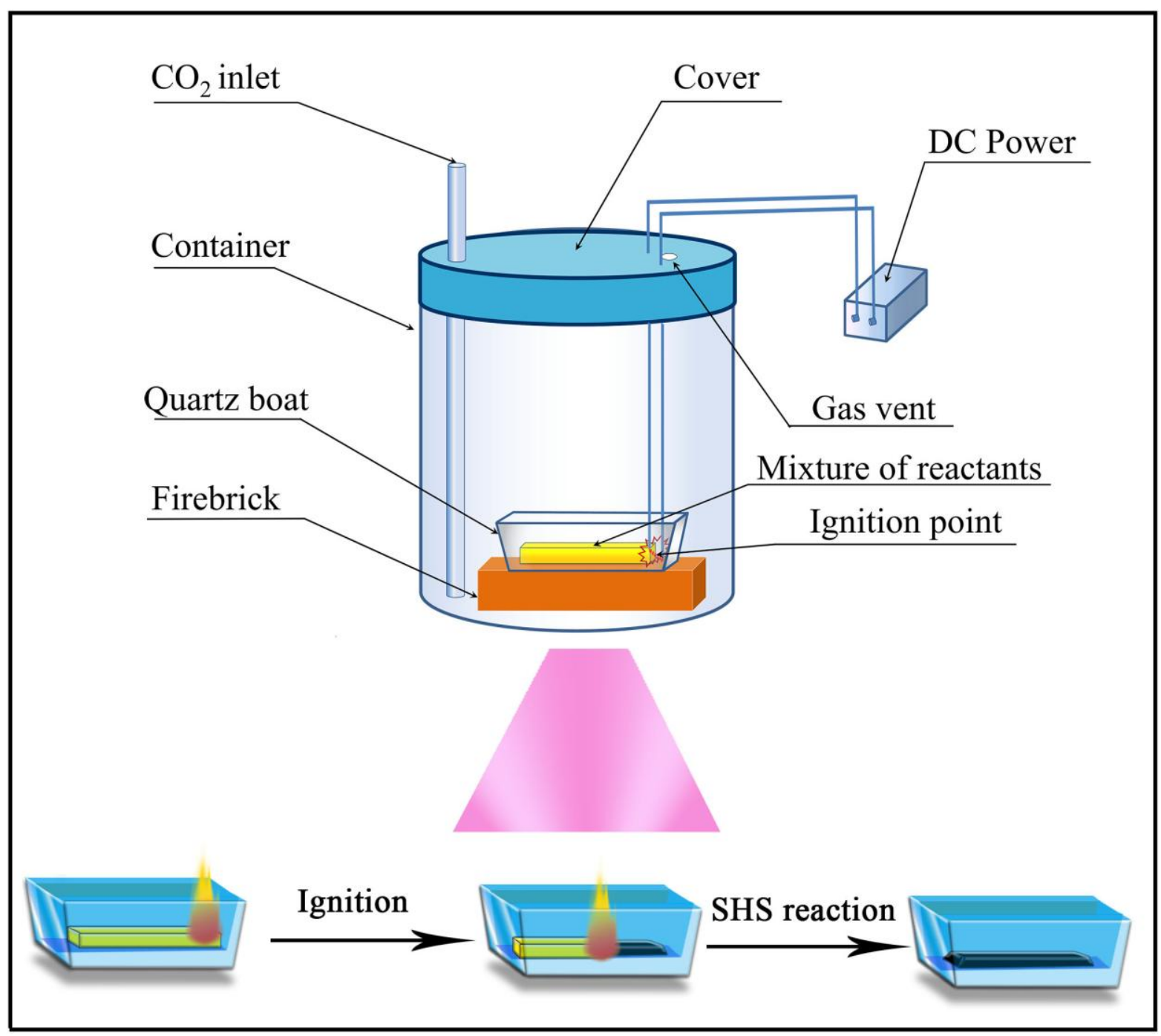

Figure 1. Schematic of the self-propagating high-temperature synthesis system.

As a contrast, $\mathrm{Mg}$ powder $(16.8 \mathrm{~g}, 99.5 \mathrm{wt} \%)$ also burned in continuous $\mathrm{CO}_{2}$ gas with a flow rate of $0.5 \mathrm{~L} \mathrm{~s}^{-1}$ in the synthesis system. In order to remove $\mathrm{MgO}, \mathrm{CaO}$ and unreacted reactants in the raw product, the raw product was washed with dilute hydrochloric acid (20 wt\%); Both the oxides in the raw product and the unreacted reactants can react with $\mathrm{HCl}$ to form soluble salts in water and thus they can be removed easily to get pure carbon material. The black product was washed with deionized water until the $\mathrm{pH}$ value of filtrate turned out to be neutral and then washed with alcohol and finally dried at $100^{\circ} \mathrm{C}$ in a vacuum drying chamber. At last, a black SHS product was obtained. The products synthesized by the reactions of $\mathrm{Mg}$ with $\mathrm{CaCO}_{3}, 3 \mathrm{MgCO}_{3} \cdot \mathrm{Mg}(\mathrm{OH})_{2} \cdot 3 \mathrm{H}_{2} \mathrm{O}, \mathrm{CO}_{2}$, glocose and PVA are denoted as $\mathrm{G}_{\mathrm{CaCO} 3}, \mathrm{G}_{\mathrm{MgCO} 3}$ and $\mathrm{G}_{\mathrm{CO} 2}, \mathrm{G}_{\mathrm{glocose}}$ and $\mathrm{G}_{\mathrm{PVA}}$, respectively. 


\subsection{Chemical analysis and textural characterization}

The microstructure of the SHS product was observed in a scanning electron microscope (SEM, Helios Nanolab 600i), and a transmission electron microscope (JEM-2100). Raman spectra were obtained using a Raman Station (B\&WTEK, BWS435-532SY) with a laser operating at $532 \mathrm{~nm}$. Powder X-ray diffraction (XRD) analyses were performed on a Philips $\mathrm{X}^{\prime}$ Pert diffractometer with $\mathrm{Cu}-\mathrm{K}_{\mathrm{a}}$ radiation $(\lambda=1.54 \AA$ ). The $\mathrm{X}$-ray photoelectron spectroscopy (XPS) measurements were conducted with a K-alpha (Thermo Fisher) system.

\subsection{Electrochemical characteristics}

A $12 \mu \mathrm{m}$ diffusion $\mathrm{TiO}_{2}$ layer (DSL 18NR-T, Dyesol) and $8 \mu \mathrm{m}$ scattering layer (WER4-O, Dyesol) were screen-printed onto the FTO (Pilkington FTO glass Tec 15) glass. The photoelectrode was sintered at $500{ }^{\circ} \mathrm{C}$ for $30 \mathrm{~min}$ in air. The sintered photo-electrode was immersed in the $\mathrm{N} 719\left(\left[\mathrm{RuL}_{2}(\mathrm{NCS})_{2}\right]: 2 \mathrm{TBA}\left(\mathrm{L}=2,2^{\prime}\right.\right.$-bipyridyl-4,4'-dicarboxylic acid; TBA = tetra-nbutylammonium), N719, Dyesol) solution $\left(3 \times 10^{-4} \mathrm{~mol} \cdot \mathrm{L}^{-1}\right)$ for $2 \mathrm{~h}$ at $50{ }^{\circ} \mathrm{C}$. The anode and cathode were packaged with the sealant $(1170$ Series, $60 \mu \mathrm{m}$, Solaronix $)$ at $125{ }^{\circ} \mathrm{C}$. The electrolyte solution was made of $0.05 \mathrm{M} \mathrm{I}_{2}, 0.5 \mathrm{M} \mathrm{N}$-methylbenzimidazole (NMBI), 1.0 M 1propyl-3-methyl-imidazolium iodide (PMII), and 0.1 M guanidinium thiocyanate (GNCS) in 2-methoxyproprionitrile (MPN) as the solvent.

\section{Results and Discussion}

The microstructures of FLG samples are shown by the SEM in Figure 2. It can be observed that $\mathrm{G}_{\mathrm{CaCO} 3}$ has a porous, almost continuous 3D structure as shown in Figure 2(a); the 3D structure of $\mathrm{G}_{\mathrm{CaCO} 3}$ is composed of thin corrugated sheets with irregular shapes. Compared with $\mathrm{G}_{\mathrm{CaCO} 3}, \mathrm{G}_{\mathrm{MgCO} 3}$ shows 3D pore structures without corrugated sheets as shown in Figure 2(b). The microstructure of $\mathrm{G}_{\text {glucose }}$ in Figure 2(c) is similar to $\mathrm{G}_{\mathrm{MgCO} 3}$ but it has a small number of corrugated graphene sheets. Compared with $\mathrm{G}_{\mathrm{CaCO} 3}, \mathrm{G}_{\mathrm{MgCO} 3}$ and $\mathrm{G}_{\text {glucose }}$, it is very interesting to observe that the $\mathrm{G}_{\mathrm{PVA}}$ sheets display novel sphere shape, and the diameter of sphere graphene can range from $20-100 \mathrm{~nm}$ as shown in the Figure 2(d). And this sphere 
graphene may be attributed to a large amount of gases released during thermal decomposition of polymer PVA in SHS reaction. MgO was a by-product in all the SHS processes and could act as a template for the preparation of graphene since graphene sheets can be grown on the $\mathrm{MgO}[49,50] . \mathrm{MgO}$ could contribute to the shape construction of the graphene sheets and be removed by $\mathrm{HCl}$.
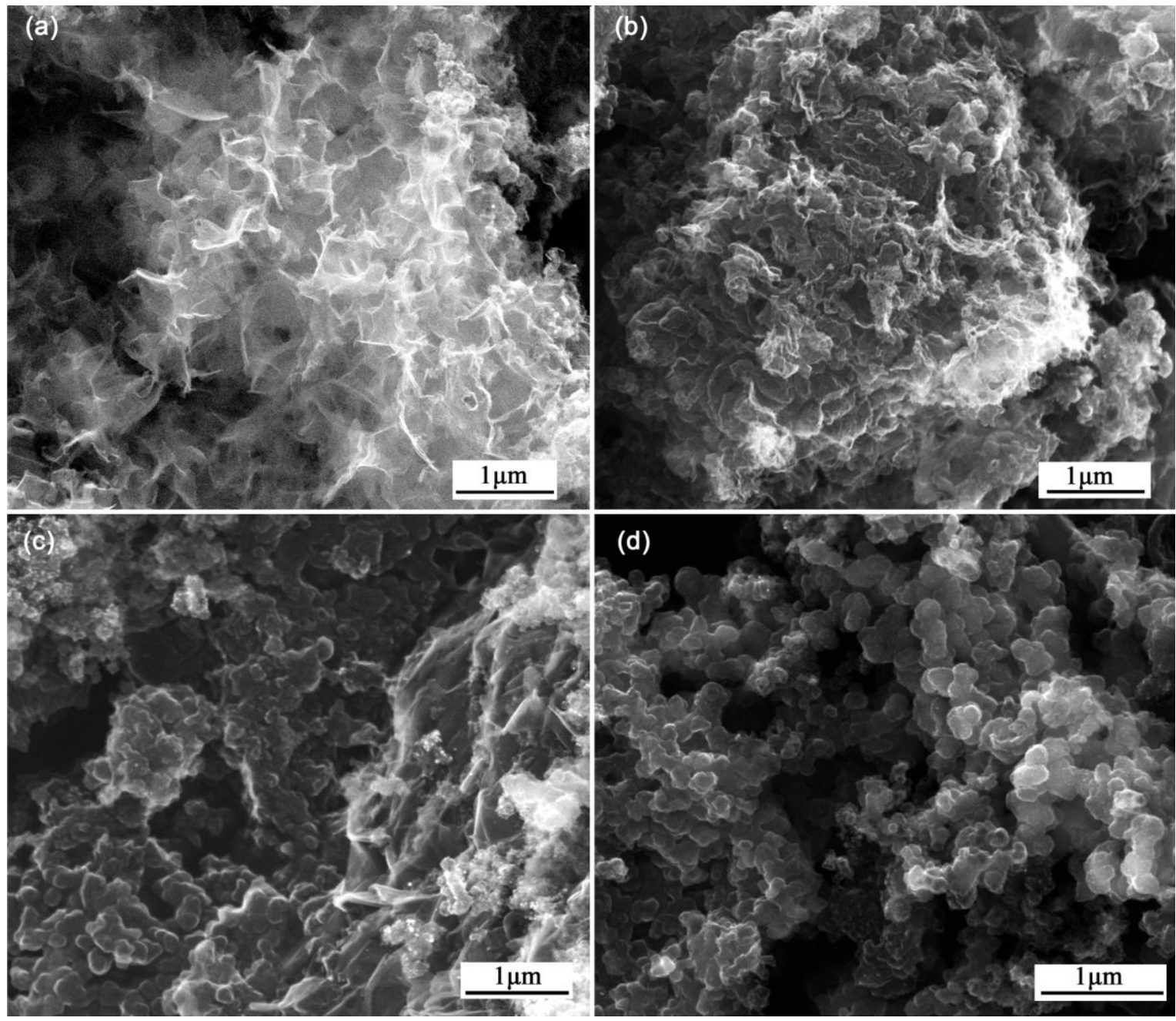

Figure 2. SEM images of the few-layer graphene samples produced from different carbon sources: (a) $\mathrm{G}_{\mathrm{CaCO} 3}$; (b) $\mathrm{G}_{\mathrm{MgCO}}$; (c) $\mathrm{G}_{\text {glucose }}$; (d) $\mathrm{G}_{\mathrm{PVA}}$. 


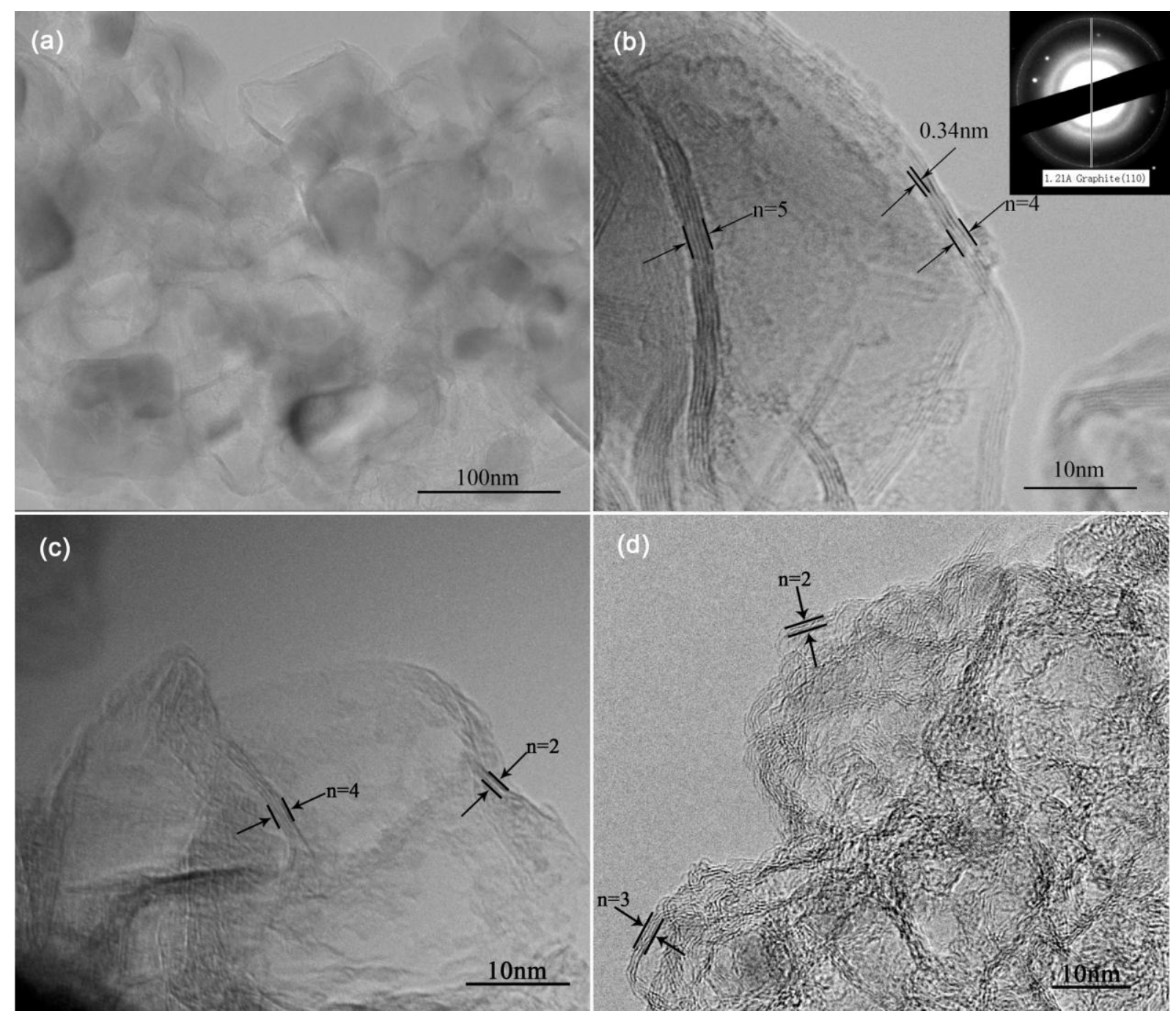

Figure 3. TEM images of the few-layer graphene: (a) TEM image of $\mathrm{G}_{\mathrm{CaCO} 3}$; (b) HRTEM of $\mathrm{G}_{\mathrm{CaCO} 3}$ sheets; (inset image: selected area electron diffraction patterns (SADP) of $\mathrm{G}_{\mathrm{CaCO} 3}$ sheets); (c) HRTEM image of $\mathrm{G}_{\text {glucose }}$; (d) HRTEM image of $\mathrm{G}_{\mathrm{PVA}}$.

Transmission electron microscopy (TEM) study was further used to investigate the morphology and crystalline structure of $\mathrm{G}_{\mathrm{CaCO} 3}$, $\mathrm{G}_{\mathrm{Glucose}}$ and $\mathrm{G}_{\mathrm{PVA}}$. A representative TEM image of $\mathrm{G}_{\mathrm{CaCO} 3}$ in Figure 3(a) clearly shows the nanostructure with a diameter $\sim 50 \mathrm{~nm}$. A high-resolution transmission electron microscopy (HRTEM) image of $\mathrm{G}_{\mathrm{CaCO} 3}$ in Figure 3(b) shows abundant edges of the graphene sheets. Generally the number of the layers of these edges approximately ranges from 3 to 8 . The typical interplanar spacing of the sheets is $\sim 0.34$ $\mathrm{nm}$ which is similar to the interplanar spacing of graphite $(002)(0.335 \mathrm{~nm})$. A corresponding SADPs of $\mathrm{G}_{\mathrm{CaCO} 3}$ has also been inserted in Figure 3(b). A clear continuous sharp Debye ring can be found which arises from nanocrystalline structure with a interplanar spacing of $1.21 \AA$ 
related to graphene (110). As shown in Figure 3(c), the HRTEM image of $G_{\text {Glucose }}$ indicates that the number of the layers is $2-4$. The sphere-shaped graphene $\left(\mathrm{G}_{\mathrm{PVA}}\right)$ is clearly displayed in Figure 3(d). The number of the layers of $\mathrm{G}_{\mathrm{PVA}}$ is about 2-5. The TEM results prove that the SHS products are FLG with special nanocrystalline structure. Both the nanostructure and the abundant thin edges of the SHS graphene may endow SHS graphene with special catalytic and electrochemical properties.

XPS spectra of FLG are shown in Figure 4. The samples were etched by Ar for 120 seconds before XPS measurement. The peaks at $1303.7 \mathrm{eV}$ and $350.14 \mathrm{eV}$ are corresponding to $\mathrm{Mg}(1 \mathrm{~s})$ and $\mathrm{Ca}(2 \mathrm{p})$, respectively, which illustrate the presence of a small amount of $\mathrm{Mg}$ and $\mathrm{Ca}$ in $\mathrm{G}_{\mathrm{CaCO} 3}$. The quantified contents of the elements $\mathrm{C}, \mathrm{O}, \mathrm{Mg}$ and $\mathrm{Ca}$ found in $\mathrm{G}_{\mathrm{CaCO} 3}$ determined by XPS are shown in Table 1. From Table 1, the main element in $\mathrm{G}_{\mathrm{CaCO} 3}$ is carbon (94.18 at\%), while the contents of $\mathrm{Mg}$ (1.11 at\%), $\mathrm{Ca}(1.01$ at $\%)$ and $\mathrm{O}$ (3.70 at\%) are much less. Element $\mathrm{O}$ could come from $\mathrm{MgO}$ and $\mathrm{CaO}$, absorbed oxygen and oxygen-containing groups in $\mathrm{G}_{\mathrm{CaCO} 3}$. Since $\mathrm{Mg}$ and $\mathrm{Ca}$ can exist in a state of oxides as $\mathrm{MgO}$ and $\mathrm{CaO}$, which means that the element $\mathrm{O}$ in oxides could be 2.12 at $\%$, and $\mathrm{O}$ content for the absorbed oxygen and the oxygen-containing groups in $\mathrm{G}_{\mathrm{CaCO} 3}$ could be less than 1.58 at $\%$. As a result, only a small quantity of carbon in $\mathrm{G}_{\mathrm{CaCO} 3}$ is in oxidization state. Compared with reactants of inorganic substance, when organic small molecule (glucose) and polymer (polyvinyl alcohol) were used as reactants, the contents of carbon were decreased to 82.56 at\% $\left(\mathrm{G}_{\mathrm{Glucose}}\right)$ and 89.90 at\% ( $\left.\mathrm{G}_{\mathrm{PVA}}\right)$ (See Table 1). This result indicates that the contents of oxygenic groups in FLG tend to be increased when the organic reactants were used in the SHS reactions. 

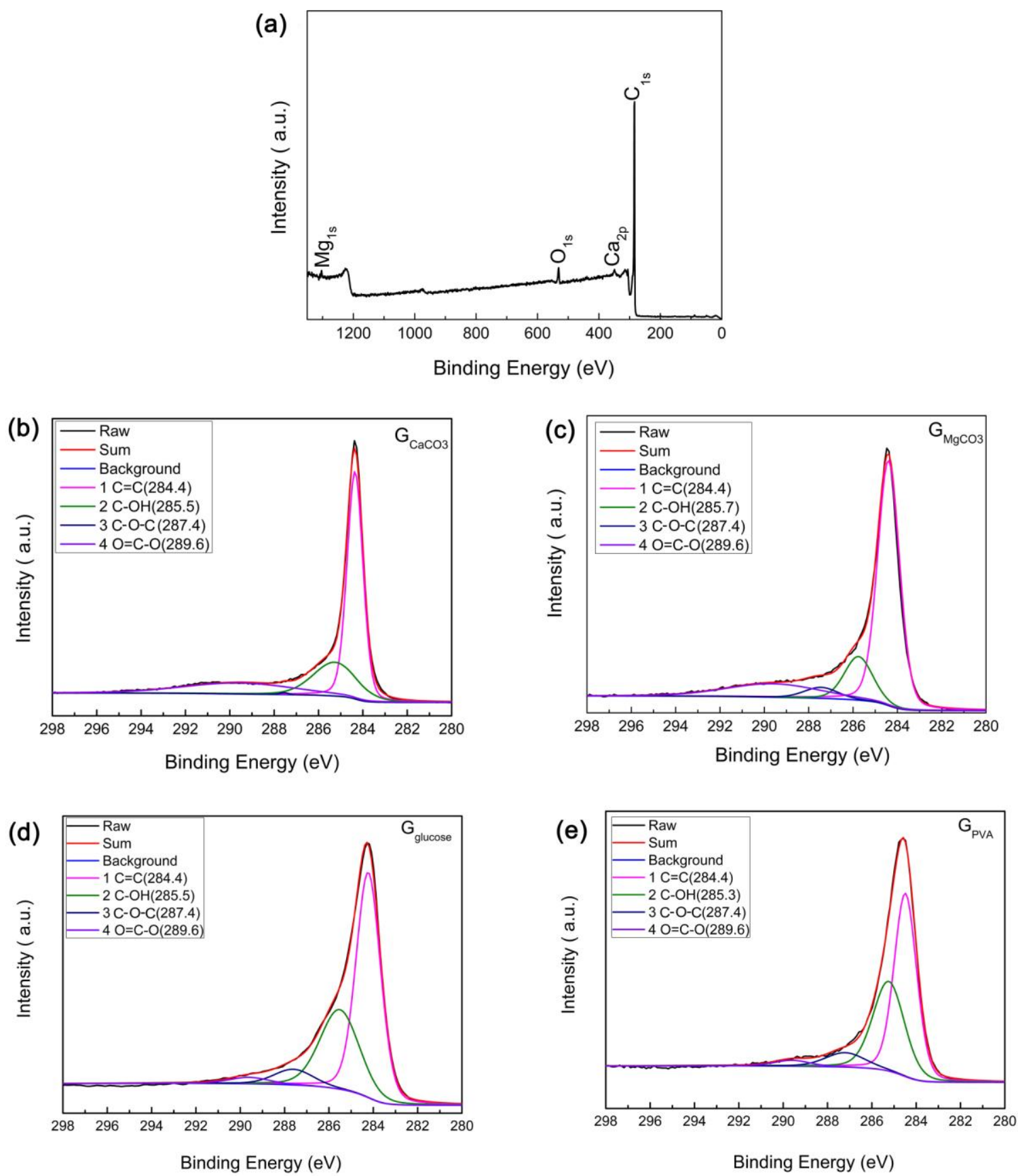

Figure 4. XPS spectra of few-layer graphene: (a) survey spectrum of $\mathrm{G}_{\mathrm{CaCO}}$; (b) $\mathrm{C}_{1 \mathrm{~s}}$ spectrum of $\mathrm{G}_{\mathrm{CaCO} 3}$; (c) $\mathrm{C}_{1 \mathrm{~s}}$ spectrum of $\mathrm{G}_{\mathrm{MgCO} 3}$; (d) $\mathrm{C}_{1 \mathrm{~s}}$ spectrum of $\mathrm{G}_{\text {glucose }}$; (e) $\mathrm{C}_{1 \mathrm{~s}}$ spectrum of $\mathrm{G}_{\mathrm{PVA}}$.

Table 1. XPS analysis of $\mathrm{C}, \mathrm{O}, \mathrm{Mg}, \mathrm{Ca}$ contents in few-layer graphene sample.

\begin{tabular}{lcccc}
\hline \multicolumn{5}{c}{ Atomic Concentration (at \%) } \\
\hline Sample & $\mathrm{C}$ & $\mathrm{O}$ & $\mathrm{Mg}$ & $\mathrm{Ca}$ \\
\hline $\mathrm{G}_{\mathrm{CaCO} 3}$ & 94.18 & 3.70 & 1.11 & 1.01 \\
$\mathrm{G}_{\mathrm{MgCO} 3}$ & 93.68 & 5.63 & 0.68 & \\
$\mathrm{G}_{\mathrm{Glucose}}$ & 82.56 & 13.1 & 4.43 & \\
$\mathrm{G}_{\mathrm{PVA}}$ & 89.90 & 9.30 & 0.80 & \\
\hline
\end{tabular}

Figure 4 (b) shows the XPS spectrum of $\mathrm{C}_{1 \mathrm{~s}}$ of $\mathrm{G}_{\mathrm{CaCO} 3}$. The peak located at $284.4 \mathrm{eV}$ 
originates from the $\mathrm{sp}^{2}$-hybridized carbon [51], the higher relative intensity of peak at 284.4 $\mathrm{eV}$ suggests that the $\mathrm{sp}^{2}$ carbon is the main state of carbon in FLG. The small peaks at 285.5 $\mathrm{eV}, 287.4 \mathrm{eV}$, and $289.6 \mathrm{eV}$ correspond to $\mathrm{C}-\mathrm{OH}, \mathrm{C}-\mathrm{O}-\mathrm{C}$ and $\mathrm{O}=\mathrm{C}-\mathrm{O}$ structure, respectively $[52,53]$, which indicate the existence of a small quantity of oxygen-containing groups.
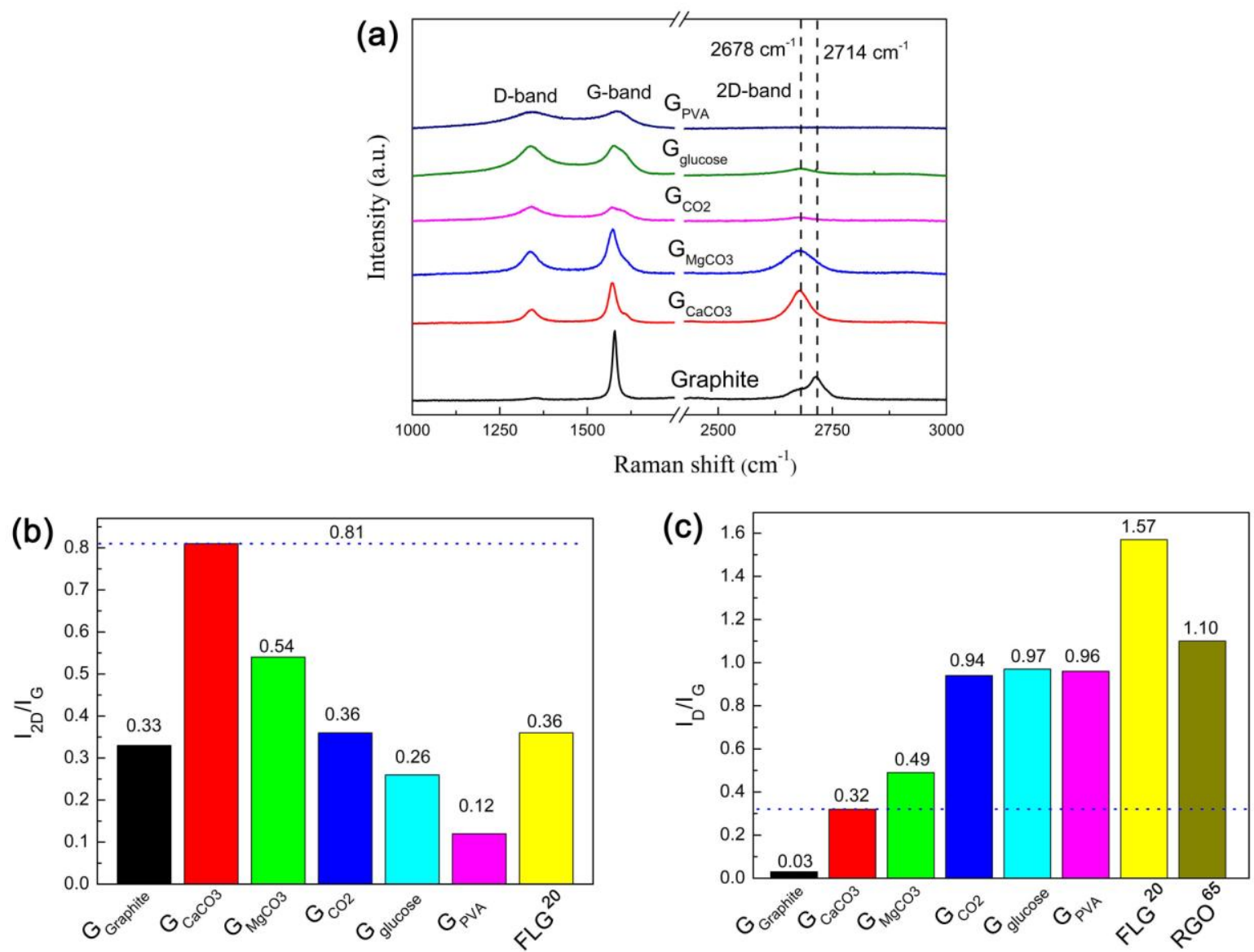

Figure 5. (a) Raman spectra of samples produced by different starting materials ; (b) histogram of $\mathrm{I}_{2 \mathrm{D}} / \mathrm{I}_{\mathrm{G}}$ corresponding to curves in (a) and $\mathrm{FLG}^{20}$; (c) histogram of $\mathrm{I}_{\mathrm{D}} / \mathrm{I}_{\mathrm{G}}$ corresponding to curves in (a), FLG ${ }^{20}$ and reduction graphene oxide (RGO) ${ }^{65}$.

Raman spectroscopy is one of the most widely used techniques to characterize the structural and electronic properties of graphene including the number of layer, disorder and defect structures, defect concentration, and doping levels [54-56]. Figure 5(a) gives the Raman spectra of SHS products synthesized from different raw materials, and as a comparison Raman spectrum of graphite is also demonstrated. The spectra were recorded under the same experimental conditions. The Raman spectra of the SHS products in Figure 
5(a) show three peaks. The $\mathrm{G}$ band at $1570 \mathrm{~cm}^{-1}$ represents the in-plane bond-stretching motion of the pairs of $\mathrm{sp}^{2}$ hybridized $\mathrm{C}$ atoms (the $\mathrm{E}_{2 \mathrm{~g}}$ phonons); while the $\mathrm{D}$ band at $1341 \mathrm{~cm}^{-}$ ${ }^{1}$ corresponds to breathing mode of rings or K-point phonons of $\mathrm{A}_{1 \mathrm{~g}}$ symmetry; the secondorder D (2D) band at $2678 \mathrm{~cm}^{-1}$ originates from a two phonon double resonance process [54, 57]. From Figure 5(a) it can be found that the 2D peaks of all SHS products $\left(2678 \mathrm{~cm}^{-1}\right)$ are greatly shift to lower wavenumber compared with that of graphite $\left(2714 \mathrm{~cm}^{-1}\right)$, which is a typical feature of FLG.

In order to observe the Raman spectra more clearly, we have separated the Raman spectra in Figure 5 (a) into 5 images as shown in Figure S1 (a) - (e). As shown in Figure S1 (a) - (d), the 2D peaks of $\mathrm{G}_{\mathrm{CaCO} 3}, \mathrm{G}_{\mathrm{MgCO} 3}, \mathrm{G}_{\mathrm{co} 2}$ and $\mathrm{G}_{\mathrm{glucose}}$ can be fitted according to Lorentzian equation, shown as the red lines. These results indicate that the materials produced by SHS method belong to turbostratic carbon. $[57,58]$

On the other hand, as reported in a recent study on the structure of graphene, the position of the $2 \mathrm{D}$ peak in the Raman spectrum can identify the presence of few-layer graphene.[22, 59] The 2D peak of few-layer graphene is distinguishable from graphite, downshift from 2730

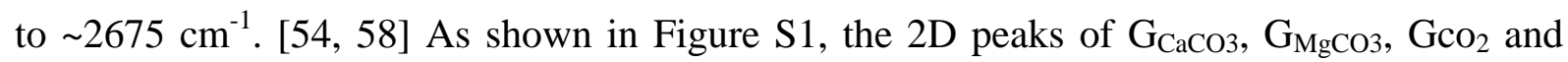
$\mathrm{G}_{\text {glucose }}$ are 2678, 2679, 2676 and $2679 \mathrm{~cm}^{-1}$, which are in agreement with the raman spectra of few-layer graphene produced by similar methods in literatures. [20, 22, 60] The features of our Raman spectra indicate that the SHS products are turbostratic few-layer graphene. In addition, the 2D peak of $\mathrm{G}_{\mathrm{PVA}}$ is almost disappeared as shown in Figure $\mathrm{S} 1$ (e), which is similar with the 2D peak of reduced graphene oxide, [61] indicating that the structure of $\mathrm{G}_{\mathrm{PVA}}$ is different from other products.

The position of the $2 \mathrm{D}$ band and the ratio of the peak intensity of $2 \mathrm{D}$ and $\mathrm{G}\left(\mathrm{I}_{2 \mathrm{D}} / \mathrm{I}_{\mathrm{G}}\right)$ have been used for the identification of the number of graphene layers $[62,63]$. The values of $I_{2 D} / I_{G}$ obtained from Figure 5(a) for samples produced from different raw materials are shown in Figure 5(b). It can be found that the $\mathrm{I}_{2 \mathrm{D}} / \mathrm{I}_{\mathrm{G}}$ values of $\mathrm{G}_{\mathrm{MgCO} 3}(0.54)$ and $\mathrm{G}_{\mathrm{CaCO} 3}(0.81)$ are much 
larger than that of graphite $(0.33)$ but also than that of FLG produced by conventional calcination from $\mathrm{Mg}$ and $\mathrm{CaCO}_{3}(0.36)$ [20]. Since the higher the value of $\mathrm{I}_{2 \mathrm{D}} / \mathrm{I}_{\mathrm{G}}$ it is, the fewer the layer number of graphene will be. ${ }^{41}$ Both of these results clearly indicate that the SHS products produced from $\mathrm{CaCO}_{3}$ and basic $\mathrm{MgCO}_{3}$ are $\mathrm{FLG}$.

Furthermore, it is generally accepted that the intensity ratio of the $\mathrm{D}$ to $\mathrm{G}$ bond $\left(\mathrm{I}_{\mathrm{D}} / \mathrm{I}_{\mathrm{G}}\right)$ can reflect the defect concentration of carbonaceous materials; the lower the ratio, the less the defect concentration [64]. As shown in Figure 5(c), the minimum value of $\mathrm{I}_{\mathrm{D}} / \mathrm{I}_{\mathrm{G}}$ of the $\mathrm{SHS}$ products is 0.32 and 0.49 corresponding to $\mathrm{G}_{\mathrm{CaCO} 3}$ and $\mathrm{G}_{\mathrm{MgCO} 3}$, while the values corresponding to $\mathrm{G}_{\mathrm{CO} 2}, \mathrm{G}_{\mathrm{Glucose}}$ and $\mathrm{G}_{\mathrm{PVA}}$ are $0.94,0.97$ and 0.96 separately. In comparison with $\mathrm{G}_{\mathrm{CaCO} 3}$ and $\mathrm{G}_{\mathrm{MgCO} 3}$, which were synthesized by inorganic matters, the values of $\mathrm{I}_{\mathrm{D}} / \mathrm{I}_{\mathrm{G}}$ of the $\mathrm{G}_{\mathrm{Glucose}}$ (micromolecule) and $\mathrm{G}_{\mathrm{PVA}}$ (macromolecule) are closed to RGO [65] and graphene synthesized by $\mathrm{CO}_{2}$. The results indicates that SHS graphene synthesized by inorganic matters has higher quality and that SHS graphene synthesized by organic matters has more defects comparable with RGO and graphene synthesized by $\mathrm{CO}_{2}$.
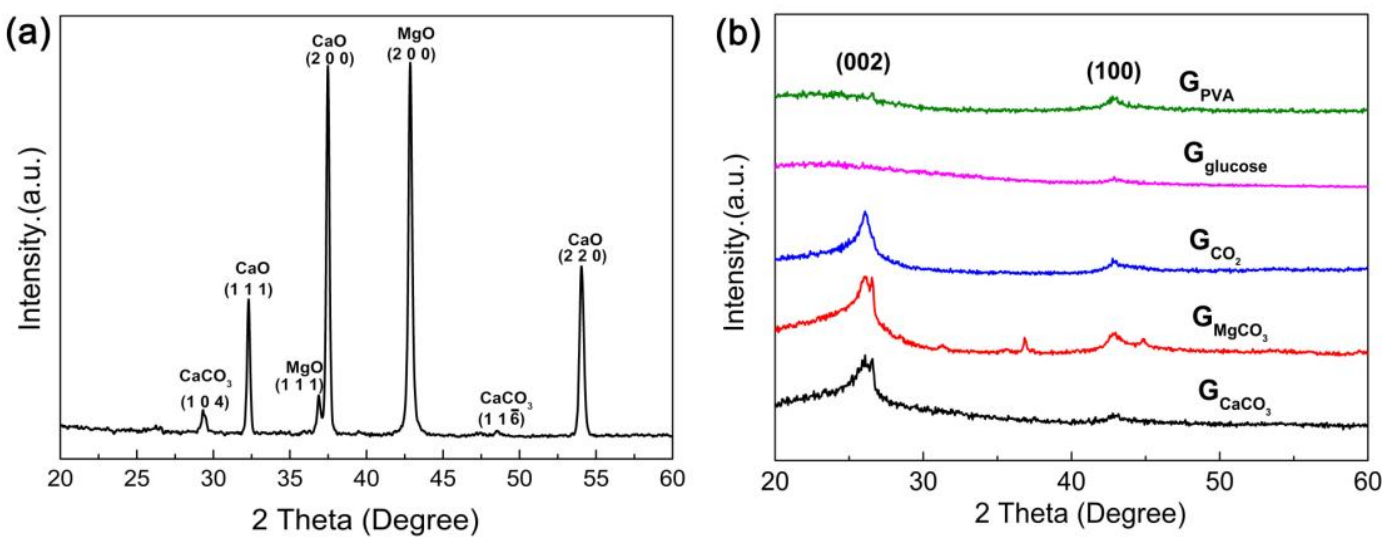

Figure 6. XRD patterns of: (a) raw $\mathrm{G}_{\mathrm{CaCO} 3}$ and (b) $\mathrm{G}_{\mathrm{CaCO} 3}, \mathrm{G}_{\mathrm{MgCO} 3}$ and $\mathrm{G}_{\mathrm{CO} 2}$ purified by $\mathrm{HCl}$.

Figure 6(a) shows XRD pattern of raw $\mathrm{G}_{\mathrm{CaCO}}$. The peaks in Figure 6(a) can be identified as $\mathrm{CaO}$ (JCPDS No. 48-1467), $\mathrm{MgO}$ (JCPDS No. 45-0946) and $\mathrm{CaCO}_{3}$ (JCPDS No. 471743), separately. XRD patterns of FLG samples produced by $\mathrm{Mg}$ with $\mathrm{CaCO}_{3}$, $3 \mathrm{MgCO}_{3} \cdot \mathrm{Mg}(\mathrm{OH})_{2} \cdot 3 \mathrm{H}_{2} \mathrm{O}$ and $\mathrm{CO}_{2}$ are similar as shown in Figure $6(\mathrm{~b})$. The most intense peak in Figure 6(b) is at $25.9^{\circ}$ corresponding to the (002) plane of FLG, and the peak at $43.2^{\circ}$ is 
assigned to (100) plane of graphene, which is another characteristic peak of graphene structure. The results are in close agreement with the literature [20, 22]. According to the analysis of FLG XRD patterns, it can be concluded that most of the $\mathrm{Mg}$ and $\mathrm{CaCO}_{3}$ have participated the reaction, and the products are $\mathrm{CaO}, \mathrm{MgO}$ and graphene. Small sum of residual $\mathrm{CaCO}_{3}$ may exist near the wall of the ceramic boat where the reaction heat is easy to be distributed and the temperature near the wall is not high enough for the reaction. Compared with $\mathrm{G}_{\mathrm{CaCO} 3}, \mathrm{G}_{\mathrm{MgCO} 3}$ and $\mathrm{G}_{\mathrm{CO} 2}$, the (002) peaks corresponding to $\mathrm{G}_{\mathrm{PVA}}$ and $\mathrm{G}_{\mathrm{Glucose}}$ are obviously broad and almost disappeared as shown in Figure 6(b), which indicates thinner or amorphous carbon exists in $\mathrm{G}_{\mathrm{PVA}}$ and $\mathrm{G}_{\mathrm{Glucose}}$. The peaks corresponding to $\mathrm{CaCO}_{3}, \mathrm{CaO}$ or $\mathrm{MgO}$ almost disappear in Figure 6(b) as compared to Figure 6(a), indicating the good purification effect of $\mathrm{HCl}$.

There are several advantages of the SHS method for graphene. Firstly, SHS method for graphene is fast and energy efficient. It only needs several minutes to finish the reactions, and it utilizes the energy released by the exothermic combustion reactions. From this aspect, it is much better than the conventional calcination method which needs heating at high temperature for several hours. Because SHS processes can produce very high temperature instantly, the volatile impurity in the reactants can be eliminated ("self-cleaning" effect) during the reaction, thus SHS graphene has low defect density and high purity.

Secondly, magnesium powder and all of the carbon sources used are abundantly available with low price, which makes the price of SHS graphene cheap enough for most of the applications. Moreover, since both the reagents and main products are solid materials, the SHS process is easy to be implemented compared to $\mathrm{CO}_{2}$ reduction method using dry ice.

Thirdly, it is a great obstacle to keep the graphene sheets individually separated during their preparation, storage and application since flat graphene sheets are generally prone to agglomerate spontaneously and even restack to form graphite as a result of strong van der Waals forces [66]. The 3D structure of SHS graphene could offer an effective solution for the 
challenge, which is useful to prevent the sheets from recombination and very useful for practical applications.

These unique advantages make SHS method a more competitive candidate toward the industrially production of 3D graphene with low price, large scale and high quality. The SHS graphene with novel 3D structure may contribute to a wide range of potential applications in nanocomposites, catalysts, energy generation and storage.

As an application of SHS graphene, the SHS graphene samples are initially used as a counter electrode in DSCs. $0.5 \mathrm{wt} \%$ polyvinylidene fluoride (PVDF) in $\mathrm{N}, \mathrm{N}-$ dimethylacetamide was used as binder to paint FLG sheets onto FTO-glass. The novel counter electrodes were shown in the inset image in Figure 7(b). We tested one group of reference DSCs with Pt counter electrode and DSCs with FLG samples. Figure 7(a) shows the normalized efficiency values of samples produced by different starting materials compared with Pt. The normalized efficiency values of $\mathrm{G}_{\mathrm{CaCO} 3}, \mathrm{G}_{\mathrm{PVA}}, \mathrm{G}_{\mathrm{CO} 2}, \mathrm{G}_{\mathrm{Glucose}}$ and $\mathrm{G}_{\mathrm{MgCO} 3}$ are $107 \%, 100 \%, 90 \%, 88 \%$ and $69 \%$, respectively. The normalized efficiency of $\mathrm{G}_{\mathrm{CaCO}}$ is the highest among the five samples. This result may be caused by the unique $3 \mathrm{D}$ structure composed of thin corrugated sheets and lower defect concentration of $\mathrm{G}_{\mathrm{CaCO} 3}$. The characteristic $J-V$ plots of the devices were shown in Figure 7(b); the detailed photovoltaic parameters are summarized in Table 2. For the DSCs with $\mathrm{G}_{\mathrm{CaCO} 3}$, the short-circuit current density $\left(J_{s c}\right)$ is measured to be $13.83 \mathrm{~mA} \mathrm{~cm}^{-2}$ yielding a total conversion efficiency of $5.4 \%$, with an open-circuit voltage $\left(V_{o c}\right)$ and fill factor $(\mathrm{FF})$ of $0.72 \mathrm{~V}$ and $54 \%$, respectively. The efficiency of $5.4 \%$ is also higher than that of $5.0 \%$ for the reference DSC with evaporated $\mathrm{Pt}$ as counter electrode. The values of $V_{o c}$ and $J_{s c}$ of DSCs with hybrid structure are slightly higher than that of DSCs with Pt.

To further understand the important parameters in the operation of the DSCs, electrochemical impedance spectroscopy (EIS) analysis employing the ZView software were carefully conducted. The EIS experiment was conducted under the dark conditions. The 
applied bias voltage is the open-circuit voltage, Voc. In the impedance measurements, the frequency range is from $100 \mathrm{mHz}$ to $1 \mathrm{MHz}$; while the amplitude of alternating current is 10 mV. As clearly shown in Figure 7(c), there are two semi-circles in the Nyquist plots. Upper inset is the zoomed-in EIS result, which clearly reflects the first semi-circle of the DSC. After the plots have been fitted with the equivalent circuit shown in the lower inset of the Figure 7c, the charge transfer resistance $\left(\mathrm{R}_{\mathrm{pt}}\right)$ of $\mathrm{G}_{\mathrm{CaCO} 3}$ was found to be $0.13 \Omega \mathrm{cm}^{2}$. This value is more than thirty times lower compared to that of the DSC having a Pt counter electrode, which is $4 \Omega \mathrm{cm}^{2}$. This proves that $\mathrm{G}_{\mathrm{CaCO} 3}$ offer lower interface resistance between the electrolyte and counter electrode, compared to the reference DSCs. The electrocatalytic activity of $\mathrm{G}_{\mathrm{CaCO} 3}$ electrode was compared to Pt electrode by measuring the cyclic voltammetry $(\mathrm{CV})$ in a threeelectrode system (Figure $7 \mathrm{~d}$ ). The typical CV curves for both $\mathrm{G}_{\mathrm{CaCO} 3}$ and Pt counter electrodes state the reactions indicative of the iodide $\left(\mathrm{I}^{-}\right) /$triiodide $\left(\mathrm{I}_{3}{ }^{-}\right)$complex redox peaks. For the $\mathrm{G}_{\mathrm{CaCO} 3}$ electrode, the peak potential for $\mathrm{I}^{-}$oxidation shifts more cathodically while the peak potential for $\mathrm{I}_{3}{ }^{-}$reduction shifts more anodically as compared to Pt electrode. In addition, the cathodic peak current density for $\mathrm{I}_{3}^{-}$reduction on $\mathrm{G}_{\mathrm{CaCO} 3}$ electrode is larger than that on $\mathrm{Pt}$ electrode. The comparison of $\mathrm{CV}$ results indicates $\mathrm{G}_{\mathrm{CaCO} 3}$ catalyzes $\mathrm{I}^{-} / \mathrm{I}_{3}{ }^{-}$redox reaction more efficiently than Pt counterpart, which is consistent with the results of full DSC performance.

Moreover, though the efficiency of the DSC with SHS graphene on non-conductive flexible substrate is only $1.8 \%$, which is not as high as some other reported FTO-free DSC $[44,67]$, we believe further work about this paintable process of preparing counter electrodes offers a much wider applications on many flexible surfaces in the future. 
(a)

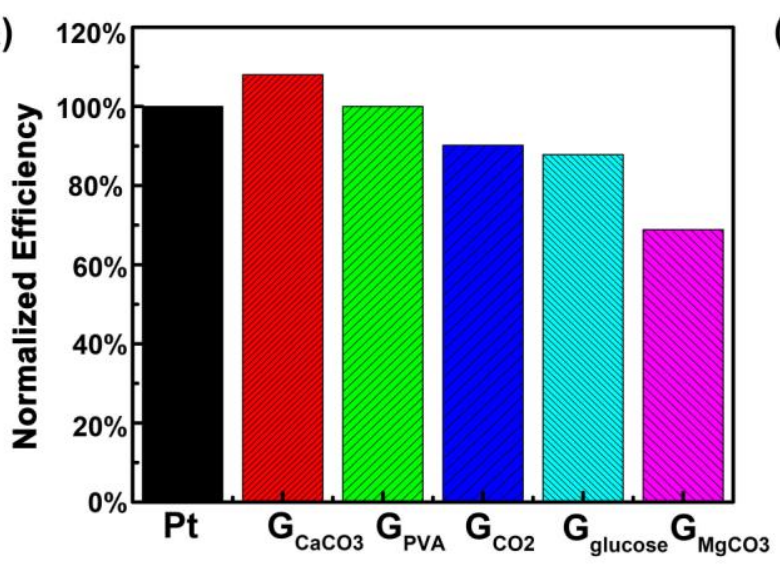

(c)

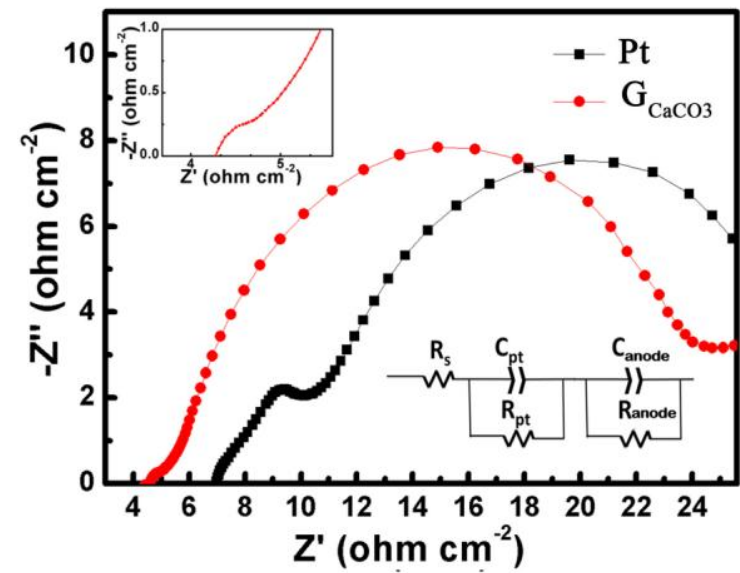

(b)

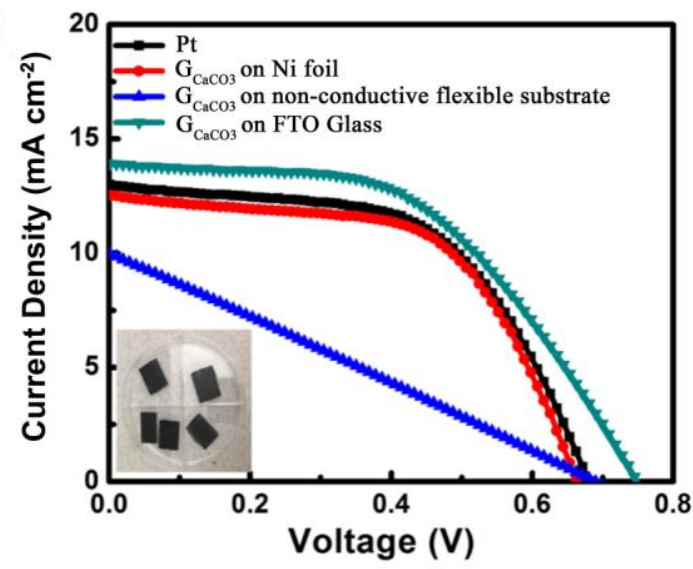

(d)

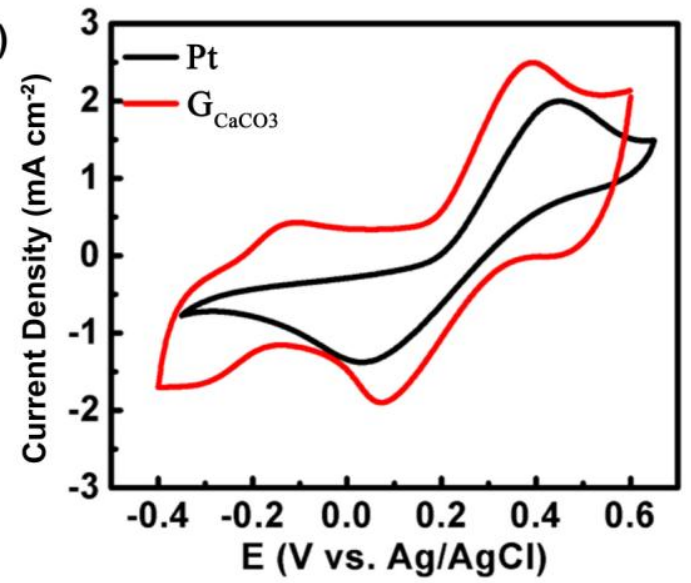

Figure 7. Photovoltaic parameters of DSCs: (a) Normalized efficiency of samples produced by different starting materials; (b) $J$ - $V$ curves of the reference and the DSCs with $\mathrm{G}_{\mathrm{CaCO} 3}$; Inset image represents the novel counter electrodes for DSCs. (c) Nyquist plots of the DSCs with $\mathrm{G}_{\mathrm{CaCO} 3}$. Upper inset is the zoomed-in EIS result, clearly reflecting the first semi-circle of the

DSC with $\mathrm{G}_{\mathrm{CaCO} 3}$. Lower inset shows the equivalent circuit used in the fitting process. (d)

Cyclic Voltammetry of $\mathrm{G}_{\mathrm{CaCO} 3}$ and $\mathrm{Pt}$ in a three-electrode setup.

Table 2. $J$ - $V$ parameters of DSC with $\mathrm{G}_{\mathrm{CaCO} 3}$

\begin{tabular}{ccccc}
\hline Counter Electrode & $\mathrm{V}_{\mathrm{oc}}[\mathrm{V}]^{\mathrm{a})}$ & $\mathrm{J}_{\mathrm{sc}}\left[\mathrm{mA} \mathrm{cm}^{-2}\right]^{\mathrm{b})}$ & $\mathrm{FF}^{\mathrm{c})}$ & $\mathrm{PCE}^{\mathrm{d})}$ \\
\hline $\begin{array}{c}\text { SHS Graphene on FTO glass } \\
\text { SHS Graphene on non-conductive } \\
\text { flexible substrate }\end{array}$ & 0.72 & 13.83 & 0.54 & $5.4 \%$ \\
Pt on FTO glass & 0.69 & 9.98 & 0.26 & $1.8 \%$ \\
\hline
\end{tabular}

a) $\mathrm{V}_{\mathrm{oc}}=$ open-circuit voltage; b) $\mathrm{J}_{\mathrm{sc}}=$ short-circuit photocurrent density; c) $\mathrm{FF}=$ fill factor; d) $\mathrm{PCE}=$ power conversion efficiency.

\section{Conclusions}

In conclusion, $\mathrm{CaCO}_{3}, 3 \mathrm{MgCO}_{3} \cdot \mathrm{Mg}(\mathrm{OH})_{2} \cdot 3 \mathrm{H}_{2} \mathrm{O}$, glucose, and polyvinyl alcohol (PVA) can be used to synthesize FLG by SHS method, which is a fast, energy efficient, highly productive and low cost method. Compared with conventional methods of fabrication of 
graphene, the SHS method has advantage of wide raw material sources such as inorganic substance $\left(\mathrm{CaCO}_{3}, 3 \mathrm{MgCO}_{3} \cdot \mathrm{Mg}(\mathrm{OH})_{2} \cdot 3 \mathrm{H}_{2} \mathrm{O}\right)$, organic small molecule (glucose), and polymer (polyvinyl alcohol) (PVA), which endows SHS method with potential commercial applications of graphene. FLG samples have different microstructure by changing of raw materials. $\mathrm{G}_{\mathrm{CaCO} 3}$ produced by SHS method has a porous structure composed of thin corrugated sheets with lower defect concentration, high purity and a nanocrystalline structure mainly made up of $\mathrm{sp}^{2}$ carbon atoms. The porous structure is beneficial to prevent the graphene sheets from recombination, which makes it more useful in many applications. The DSCs with $\mathrm{G}_{\mathrm{CaCO} 3}$ achieved an efficiency of $5.4 \%$, higher than $5.0 \%$ obtained with a reference DSCs with Pt. EIS results found the $\mathrm{R}_{\mathrm{pt}}$ of $\mathrm{G}_{\mathrm{CaCO} 3}$ to be $0.13 \Omega \mathrm{cm}^{2}$ which is more than thirty times lower than that of the DSC having a Pt counter electrode. $\mathrm{G}_{\mathrm{CaCO} 3}$ has been demonstrated to be an alternative counter electrode in DSC. In the future, SHS method is also very promising to be designed to produce doped graphene or graphene based composites by choosing different reagents.

\section{Acknowledgments}

The authors gratefully acknowledge the support from the National Basic Research Program of China (No.2011CB612200), China Scholarship Council (No.201206125006) and Harbin Key Technologies R\&D Programme (2012DB2CP029). PD, ZL and JL acknowledge the funding support from the Welch Foundation (C-1716) and the Shell Center for Sustainability at Rice University. RV and PMA specially acknowledge funding from the DOD: Air Force Office of Scientific Research for the Project MURI: Synthesis and Characterization of 3D Carbon Nanotube Solid Networks, Award No.: FA9550-12-1-0035.

\section{References}

[1] Morozov SV, Novoselov KS, Katsnelson MI, Schedin F, Elias DC, Jaszczak JA, et al. Giant intrinsic carrier mobilities in graphene and its bilayer. Physical review letters. 2008;100:016602. 
[2] Balandin AA, Ghosh S, Bao W, Calizo I, Teweldebrhan D, Miao F, et al. Superior thermal conductivity of single-layer graphene. Nano letters. 2008;8:902-7.

[3] Lee C, Wei XD, Kysar JW, Hone J. Measurement of the elastic properties and intrinsic strength of monolayer graphene. Science. 2008;321:385-8.

[4] Bunch JS, Verbridge SS, Alden JS, van der Zande AM, Parpia JM, Craighead HG, et al. Impermeable atomic membranes from graphene sheets. Nano letters. 2008;8:2458-62.

[5] Nair RR, Blake P, Grigorenko AN, Novoselov KS, Booth TJ, Stauber T, et al. Fine structure constant defines visual transparency of graphene. Science. 2008;320:1308.

[6] Novoselov KS, Geim AK, Morozov SV, Jiang D, Zhang Y, Dubonos SV, et al. Electric field effect in atomically thin carbon films. Science. 2004;306:666-9.

[7] Berger C, Song Z, Li T, Li X, Ogbazghi AY, Feng R, et al. Ultrathin Epitaxial Graphite: 2D Electron Gas Properties and a Route toward Graphene-based Nanoelectronics. J Phys Chem B. 2004;108:19912-6.

[8] Hernandez Y, Nicolosi V, Lotya M, Blighe FM, Sun Z, De S, et al. High-yield production of graphene by liquid-phase exfoliation of graphite. Nature nanotechnology. 2008;3:563-8.

[9] Qian M, Zhou YS, Gao Y, Park JB, Feng T, Huang SM, et al. Formation of graphene sheets through laser exfoliation of highly ordered pyrolytic graphite. Appl Phys Lett.

2011;98:173108.

[10] Zhao G, Shao D, Chen C, Wang X. Synthesis of few-layered graphene by H[sub 2]O[sub 2] plasma etching of graphite. Appl Phys Lett. 2011;98:183114.

[11] Kosynkin DV, Higginbotham AL, Sinitskii A, Lomeda JR, Dimiev A, Price BK, et al. Longitudinal unzipping of carbon nanotubes to form graphene nanoribbons. Nature.

2009;458:872-6.

[12] Jr. WSH, Offeman RE. Preparation of Graphitic Oxide. J Am Chem Soc. 1958;80:1339-.

[13] Li D, Muller MB, Gilje S, Kaner RB, Wallace GG. Processable aqueous dispersions of graphene nanosheets. Nature nanotechnology. 2008;3:101-5.

[14] Niyogi S, Bekyarova E, Itkis ME, McWilliams JL, Hamon MA, Haddon RC. Solution properties of graphite and graphene. Journal of the American Chemical Society.

2006;128:7720-1.

[15] Kim KS, Zhao Y, Jang H, Lee SY, Kim JM, Kim KS, et al. Large-scale pattern growth of graphene films for stretchable transparent electrodes. Nature. 2009;457:706-10.

[16] Reina A, Jia X, Ho J, Nezich D, Son H, Bulovic V, et al. Large area, few-layer graphene films on arbitrary substrates by chemical vapor deposition. Nano letters. 2009;9:30-5.

[17] Berger C, Song Z, Li X, Wu X, Brown N, Naud C, et al. Electronic confinement and coherence in patterned epitaxial graphene. Science. 2006;312:1191-6.

[18] Wu Y, Wang B, Ma Y, Huang Y, Li N, Zhang F, et al. Efficient and large-scale synthesis of few-layered graphene using an arc-discharge method and conductivity studies of the resulting films. Nano Res. 2010;3:661-9.

[19] Yin H, Chen P, Xu C, Gao X, Zhou Q, Zhao Y, et al. Shock-wave synthesis of multilayer graphene and nitrogen-doped graphene materials from carbonate. Carbon. 2015;94:928-35.

[20] Zhao J, Guo Y, Li Z, Guo Q, Shi J, Wang L, et al. An approach for synthesizing graphene with calcium carbonate and magnesium. Carbon. 2012;50:4939-44.

[21] Kim C-D, Min B-K, Jung W-S. Preparation of graphene sheets by the reduction of carbon monoxide. Carbon. 2009;47:1610-2.

[22] Chakrabarti A, Lu J, Skrabutenas JC, Xu T, Xiao Z, Maguire JA, et al. Conversion of carbon dioxide to few-layer graphene. Journal of Materials Chemistry. 2011;21:9491.

[23] Merzhanov AG. Theory and practice of SHS: worldwide state of the art and the newest results. International Journal on Self-Propagating High-Temperature Synthesis. 1993;2:11358.

[24] Merzhanov AG. Combustion and Plasma Synthesis of High-Temperature Materials. New York: CVH Publishers; 1990. 
[25] Merzhanov AG, Borovinskaya IP. self-propagating high-temperature synthesis of refractory inorganic compounds. Dokl Akad Nauk SSR. 1972:366-9.

[26] Liu G, Chen K, Zhou H, Guo J, Ren K, Ferreira JMF. Layered growth of Ti2AlC and Ti3AlC2 in combustion synthesis. Mater Lett. 2007;61:779-84.

[27] Liu G, Yang K, Li J, Yang K, Du J, Hou X. Combustion Synthesis of Nanosized B -SiC Powder on a Large Scale. J Phys Chem C. 2008;112:6285-92.

[28] Yeh CL, Wang HJ. Combustion synthesis of vanadium borides. J Alloy Compd. 2011;509:3257-61.

[29] Jin H-B, Yang Y, Chen Y-X, Lin Z-M, Li J-T. Mechanochemical-Activation-Assisted Combustion Synthesis of alpha-Si3N4. J Am Ceram Soc. 2006;89:1099-102.

[30] Liu G, Chen K, Zhou H, Tian J, Pereira C, Ferreira JMF. Fast Shape Evolution of TiN Microcrystals in Combustion Synthesis. Cryst Growth Des. 2006;6:2404-11.

[31] Yang H, Lin Y, Zhu J, Wang F. Low-Temperature Combustion Synthesis of NaNbO3 Powders. Mater Manuf Process. 2009;24:550-3.

[32] Zec S, Dukić J, Puševac M, Bošković S, Petrović R. Sol-Gel Combustion Synthesis of La9.33(SiO4)6O2Oxyapatite. Mater Manuf Process. 2009;24:1104-8.

[33] Oregan B, Gratzel M. A Low-Cost, High-Efficiency Solar-Cell Based on Dye-Sensitized Colloidal Tio2 Films. Nature. 1991;353:737-40.

[34] Kakiage K, Aoyama Y, Yano T, Oya K, Fujisawa J, Hanaya M. Highly-efficient dyesensitized solar cells with collaborative sensitization by silyl-anchor and carboxy-anchor dyes. Chemical communications. 2015;51:15894-7.

[35] Han LY, Islam A, Chen H, Malapaka C, Chiranjeevi B, Zhang SF, et al. High-efficiency dye-sensitized solar cell with a novel co-adsorbent. Energ Environ Sci. 2012;5:6057-60.

[36] Wongcharee K, Meeyoo V, Chavadej S. Dye-sensitized Solar Cell Using Natural Dyes

Extracted from Rosella and Blue Pea Flowers. Sol Energ Mat Sol C. 2007;91:566-71.

[37] Polo AS, Iha NYM. Blue Sensitizers for Solar Cells: Natural Dyes from Calafate and Jaboticaba. Sol Energ Mat Sol C. 2006;90:1936-44.

[38] Smestad G, Bignozzi C, Argazzi R. Testing of Dye Sensitized TiO2 Solar Cells I:

Experimental Photocurrent Output and Conversion Efficiencies. Sol Energy Mater Sol Cells. 1994;32:259-72.

[39] Nam JG, Park YJ, Kim BS, Lee JS. Enhancement of the efficiency of dye-sensitized solar cell by utilizing carbon nanotube counter electrode. Scripta Mater. 2010;62:148-50. [40] Imoto K, Takahashi K, Yamaguchi T, Komura T, Nakamura J, Murata K. Highperformance carbon counter electrode for dye-sensitized solar cells. Sol Energ Mat Sol C. 2003;79:459-69.

[41] Murakami TN, Ito S, Wang Q, Nazeeruddin MK, Bessho T, Cesar I, et al. Highly efficient dye-sensitized solar cells based on carbon black counter electrodes. J Electrochem Soc. 2006;153:A2255-A61.

[42] Kay A, Gratzel M. Low cost photovoltaic modules based on dye sensitized nanocrystalline titanium dioxide and carbon powder. Sol Energ Mat Sol C. 1996;44:99-117.

[43] Kavan L, Yum J-H, Graetzel M. Graphene-based cathodes for liquid-junction dye sensitized solar cells: Electrocatalytic and mass transport effects. Electrochimica Acta. 2014;128:349-59.

[44] Kavan L, Liska P, Zakeeruddin SM, Gratzel M. Optically transparent FTO-free cathode for dye-sensitized solar cells. ACS applied materials \& interfaces. 2014;6:22343-50.

[45] Kavan L. Exploiting nanocarbons in dye-sensitized solar cells. Topics in current chemistry. 2014;348:53-93.

[46] Kavan L, Yum JH, Graetzel M. Optically transparent cathode for Co(III/II) mediated dye-sensitized solar cells based on graphene oxide. ACS applied materials \& interfaces.

2012;4:6999-7006. 
[47] Kavan L, Yum JH, Nazeeruddin MK, Gratzel M. Graphene nanoplatelet cathode for Co(III)/(II) mediated dye-sensitized solar cells. ACS nano. 2011;5:9171-8.

[48] Kavan L, Yum JH, Gratzel M. Graphene nanoplatelets outperforming platinum as the electrocatalyst in co-bipyridine-mediated dye-sensitized solar cells. Nano Lett. 2011;11:55016.

[49] Gaddam S, Bjelkevig C, Ge S, Fukutani K, Dowben PA, Kelber JA. Direct graphene growth on MgO: origin of the band gap. Journal of physics Condensed matter : an Institute of Physics journal. 2011;23:072204.

[50] Zhao J, Zhu G, Huang W, He Z, Feng X, Ma Y, et al. Synthesis of large-scale undoped and nitrogen-doped amorphous graphene on $\mathrm{MgO}$ substrate by chemical vapor deposition. Journal of Materials Chemistry. 2012;22:19679.

[51] Ruan G, Sun Z, Peng Z, Tour JM. Growth of graphene from food, insects, and waste. ACS nano. 2011;5:7601-7.

[52] Jeong HK, Lee YP, Lahaye RJ, Park MH, An KH, Kim IJ, et al. Evidence of graphitic AB stacking order of graphite oxides. Journal of the American Chemical Society. 2008;130:1362-6.

[53] Shen Y, Jing T, Ren W, Zhang J, Jiang Z-G, Yu Z-Z, et al. Chemical and thermal reduction of graphene oxide and its electrically conductive polylactic acid nanocomposites. Composites Science and Technology. 2012;72:1430-5.

[54] Ferrari AC, Meyer JC, Scardaci V, Casiraghi C, Lazzeri M, Mauri F, et al. Raman spectrum of graphene and graphene layers. Physical review letters. 2006;97:187401.

[55] Zhu C, Guo S, Fang Y, Dong S. Reducing sugar: new functional molecules for the green synthesis of graphene nanosheets. ACS nano. 2010;4:2429-37.

[56] Gupta A, Chen G, Joshi P, Tadigadapa S, Eklund PC. Raman scattering from highfrequency phonons in supported n-graphene layer films. Nano letters. 2006;6:2667-73.

[57] Ferrari AC, Basko DM. Raman spectroscopy as a versatile tool for studying the properties of graphene. Nature nanotechnology. 2013.

[58] Malard LM, Pimenta MA, Dresselhaus G, Dresselhaus MS. Raman spectroscopy in graphene. Physics Reports. 2009;473:51-87.

[59] Acharya KP, Khatri H, Marsillac S, Ullrich B, Anzenbacher P, Zamkov M. Pulsed laser deposition of graphite counter electrodes for dye-sensitized solar cells. Appl Phys Lett. $2010 ; 97$.

[60] Bianco F, Miseikis V, Convertino D, Xu JH, Castellano F, Beere HE, et al. THz saturable absorption in turbostratic multilayer graphene on silicon carbide. Optics express.

2015;23:11632-40.

[61] Eda G, Chhowalla M. Chemically derived graphene oxide: towards large-area thin-film electronics and optoelectronics. Advanced materials. 2010;22:2392-415.

[62] Basko DM, Piscanec S, Ferrari AC. Electron-electron interactions and doping dependence of the two-phonon Raman intensity in graphene. Physical Review B. 2009;80.

[63] Calizo I, Bejenari I, Rahman M, Liu G, Balandin AA. Ultraviolet Raman microscopy of single and multilayer graphene. Journal of Applied Physics. 2009;106:043509.

[64] Eckmann A, Felten A, Verzhbitskiy I, Davey R, Casiraghi C. Raman study on defective graphene: Effect of the excitation energy, type, and amount of defects. Physical Review B. 2013;88.

[65] Dong XC, Xu H, Wang XW, Huang YX, Chan-Park MB, Zhang H, et al. 3D graphenecobalt oxide electrode for high-performance supercapacitor and enzymeless glucose detection. ACS nano. 2012;6:3206-13.

[66] Stankovich S, Dikin DA, Piner RD, Kohlhaas KA, Kleinhammes A, Jia Y, et al. Synthesis of graphene-based nanosheets via chemical reduction of exfoliated graphite oxide. Carbon. 2007;45:1558-65. 
[67] Dong P, Zhu Y, Zhang J, Hao F, Wu J, Lei S, et al. Vertically Aligned Carbon Nanotubes/Graphene Hybrid Electrode as a TCO- and Pt-Free Flexible Cathode for Application in Solar Cells. J Mater Chem A. 2014;2:20902-7. 